\title{
The National Dutch Breast Implant Registry: user-reported experiences and importance
}

\author{
Claudia Antoinette Bargon ${ }^{1,2}$. Babette E. Becherer ${ }^{3,4}$. Danny Young-Afat ${ }^{5}$. Annelotte C. M. van Bommel ${ }^{6}$. \\ Juliette Hommes ${ }^{7}$ - Marije J. Hoornweg ${ }^{8} \cdot$ Ingrid Hopper $^{9}$ - Marc A. M. Mureau ${ }^{10}$ • Hinne A. Rakhorst ${ }^{11}$ (I)
}

Received: 25 March 2020 / Accepted: 4 May 2020

(C) Springer-Verlag GmbH Germany, part of Springer Nature 2020

\begin{abstract}
Background Robust (inter-)national breast implant registries are important. For some, registries are an administrative burden, for others they represent a solution for the discussions involving breast implants. The DBIR is one of the first national, opt-out, clinical registries of breast implants, providing information for clinical auditing and product recall. Four years after its introduction, it is time to address users' comments in order to keep improving quality of registration, and patient safety. This study assesses users' feedback focusing on importance of registration, logistics and user experience, and areas of improvement.

Methods In May 2018, a standardized online study-specific questionnaire was sent out to all members of the Netherlands Society of Plastic Surgery. Descriptive statistics were reported in absolute frequencies and/or percentages.

Results A total of 102 members responded to the questionnaire (response rate, 24.2\%). Of all respondents, 97.1\% were actively registering in DBIR. Respondents rated the importance of registration in DBIR as 8.1 out of 10 points. Ninety-one respondents suggested improvements for the DBIR. All comments were related to registration convenience and provision of automatically generated data.

Conclusions Respondents believe that registration is highly important and worth the administrative burden. However, we should collectively keep improving accuracy, usability and sustainability of breast implant registries. The primary focus should be on the user interface; on user friendliness, automation, and data reusability. These users' responses function as a new incentive and provide learning points that are easy to extrapolate to others who want to set up or improve breast implant registries.

Level of evidence: Not ratable.
\end{abstract}

Keywords Breast implants · Implant registry $\cdot$ Clinical auditing $\cdot$ Quality of care

Hinne A. Rakhorst

rakhorst@gmail.com

1 Department of Plastic, Reconstructive and Hand Surgery, St. Antonius Hospital, Nieuwegein, The Netherlands

2 Department of Oncological Surgery, St. Antonius Hospital, Nieuwegein, The Netherlands

3 Dutch Institute for Clinical Auditing (DICA), Leiden, The Netherlands

4 Department of Plastic and Reconstructive Surgery, Erasmus Medical Centre Cancer Institute, University Medical Center, Rotterdam, The Netherlands

5 Department of Plastic, Reconstructive and Hand Surgery, Amsterdam University Medical Centre,

Amsterdam, The Netherlands
6 Department of Plastic, Reconstructive and Hand Surgery, University Medical Centre Utrecht, Utrecht, The Netherlands

7 Department of Plastic, Reconstructive and Hand Surgery, Maastricht University Medical Centre, Maastricht, The Netherlands

8 Department of Plastic, Reconstructive and Hand Surgery, Netherlands Cancer Institute (Antoni van Leeuwenhoek), Amsterdam, The Netherlands

9 Department of Epidemiology and Preventive Medicine, Monash University, Melbourne, Australia

10 Department of Plastic and Reconstructive Surgery, Erasmus Medical Centre Cancer Institute, University Medical Centre Rotterdam, Rotterdam, The Netherlands

11 Department of Plastic, Reconstructive and Hand Surgery, Medisch Spectrum Twente/Ziekenhuisgroep Twente, Koningsplein 1, 7512 KZ Enschede, The Netherlands 


\section{Introduction}

Breast implants are one of the most commonly used medical devices, classified as high-risk class III devices [1, 2]. Worldwide, approximately 5-10 million women have breast implants [3]. In the Netherlands, approximately $3.0 \%$ of all women between 20 and 70 years old carried a breast implant in 2019 [2, 4].

Since their introduction, the adverse effects of breast implants have been under debate, including the breast implantassociated-anaplastic large cell lymphoma (BIA-ALCL) [5, 6]. Risks are usually calculated by determining denominator data such as the total number of women with a breast implant. However, this has shown to be a major challenge for one of the most used implants in medicine, which underlines the importance of robust and nationwide breast implant registries.

In the Netherlands, the Dutch Breast Implant Registry (DBIR) was introduced in 2015 [7]. The DBIR is a national opt-out and mandatory clinical registry that registers patient, operation, and implant characteristics from all patients undergoing implantation and explantation of breast implants, and breast tissue expanders. The registry provides information for clinical auditing and it can be used to identify patients in case of a hazard alert or product recall, using social security numbers. Data are entered either by batch uploads from the hospital patient files, via an online portal, or by paper forms which are subsequently registered in the online portal. Registration of breast implants in DBIR is mandatory for all board-certified plastic surgeons in the Netherlands, and only board-certified plastic surgeons are allowed to perform breast implant- or breast tissue expander-based surgery.

Today, the DBIR is growing into a mature, opt-out registry [8], and together with Sweden and Australia, it is one of the three leaders in breast implant registration. In 2016, $89 \%$ of the eligible number of institutions known by the Dutch Health and Youth Care Inspectorate (IGJ) participated in registration in the DBIR (95\% of the hospitals, $78 \%$ of the private clinics) [8]. By the start of 2018, 38,000 implants had been registered in 18,000 women [8].

Even though stakeholders understand and appreciate the importance of this registry [9], long-term funding commitments remain a challenge and subject of discussion. In addition, registering data is time consuming for plastic surgeons (time spent by the surgeon to register a revision case being approximately 5-10 min). This leads to questions, such as: "What do the users think of the registry?", "Do they find the registry important?", "What are current user experiences and what should we focus on to improve ease of use?'. Four years after its introduction, it is time to ask feedback from the users in order to move forward and keep improving the quality of registration and patient safety. Therefore, the aim of this study was to assess feedback of the users focusing on 3 domains: (A) importance of registration, (B) logistics and user experience, and $(\mathrm{C})$ areas of improvement.

\section{Material and methods}

\section{Design}

In May 2018, a standardized online study-specific questionnaire was designed. After a pilot survey among the DBIR committee was completed, the questionnaire was sent out by email to all plastic surgeons and plastic surgery residents who are members of the Netherlands Society of Plastic Surgery (NVPC). The current study was centrally approved by the scientific board of the DBIR, and the NVPC. Respondents consented to the use of this data for anonymized publication. The Medical Research Involving Human Subjects Act (WMO) does not apply to this study.

\section{Questionnaire}

The online questionnaire covered three domains: (A) importance of registration, (B) logistics and user experience, and (C) areas of improvement. Users were given the option to complete a short or a long version of the questionnaire up to their own preference. The short version included 9 or 12 questions (dependent on whether the respondent indicated that he or she personally enters data into DBIR), and the long version included 16 or 18 questions. The survey consisted of openended questions with space to enter free text, and closed questions. Closed questions were either multiple choice or required a single answer.

\section{Database and statistical analysis}

The questionnaire was set up in SurveyMonkey®, an online questionnaire collection program that conforms to the General Data Protection Regulation (GDPR). Survey responses were analyzed in a de-identified manner. Descriptive statistics were reported in absolute frequencies and/or percentages.

\section{Results}

\section{Demographics}

All members of the NVPC (i.e., 422 plastic surgeons, plastic surgery residents and physician assistants) were invited to participate. A total of 102 members responded to the questionnaire (response rate, 24.2\%). Of the respondents, 85 (83.3\%) were board-certified plastic surgeons, $15(14.7 \%)$ were residents in plastic surgery and 2 (2.0\%) were physician assistants (Table 1$)$. The long form was completed by $70(68.7 \%)$ respondents, and the short form by $32(31.4 \%)$ respondents.

A total of 99 of 102 respondents $(97.1 \%)$ were actively registering in the DBIR. Respondents worked at 60 different institutions in the Netherlands (Fig. 1). Thirty-two (31.4\%) 
Table 1

Characteristics of respondents

No.

Types of healthcare institution

\begin{tabular}{lll} 
Academic & 21 & 20.6 \\
Non-academic & 73 & 71.5 \\
Private or independent treatment center & 44 & 43.1 \\
Two or more types & 32 & 31.4 \\
Role of respondent & & \\
Board-certified plastic surgeon & 85 & 83.3 \\
Plastic surgery resident & 15 & 14.7 \\
Physician assistant & 2 & 2.0 \\
Total respondents & 102 & 100 \\
\hline
\end{tabular}

respondents worked at two or more types of medical centers (e.g. academic hospital and private clinic). Twenty-one respondents $(20.6 \%)$ worked in an academic hospital, 73 (71.5\%) in a non-academic hospital, and $44(43.1 \%)$ in a private clinic or independent treatment center (Table 1).

\section{Importance of registration}

On average, respondents rated the importance of registration of breast implants in DBIR as 8.1 out of 10 points. None of the respondents encountered patients who wished to opt-out the registration of their breast implant(s).

A total of $97 \%$ of all respondents reported that they register in the DBIR. Ninety-two respondents $(90.2 \%)$ registered because of the national obligation for registration of medical implants, $75(73.5 \%)$ registered because registration is mandatory for all board-certified plastic surgeons in the Netherlands, 24 (23.5\%) registered to support data collection for the Dutch Health and Youth Care Inspectorate (i.e., these

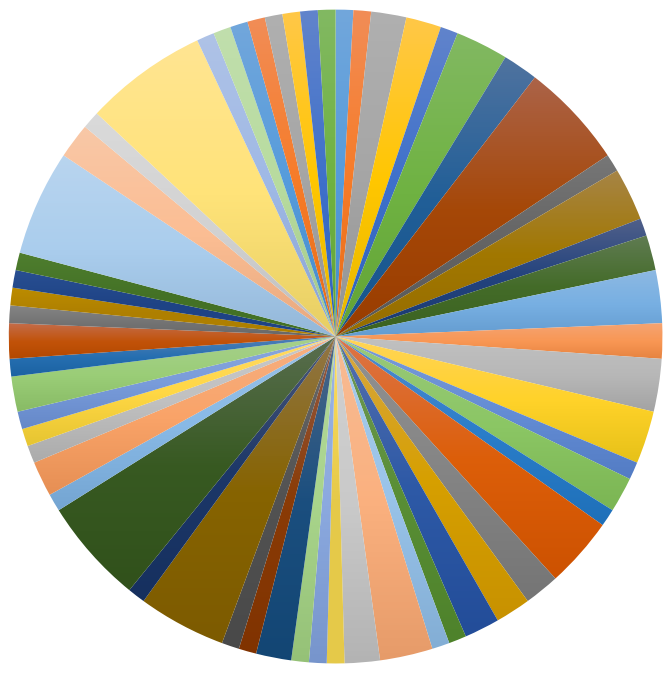

Admiraal de Ruyter Ziekenhuis
Amphia Ziekenhuis
Bauland Kliniek
Catharina Ziekenhuis
Deventer Ziekenhuis
Elisabeth-TweeSteden Ziekenhuis
Franciscus Gasthuis
- Haga Ziekenhuis
Ikazia Ziekenhuis
Kliniek Veldhoven
Maxima Medisch Centrum
Medisch Centrum Leeuwarden
Ziekenhuis Nij Smellinghe
Park Medisch Centrum
Bijnstate Ziekenhuis
- St. Jans Gasthuis Weert

- Alexander Monro Ziekenhuis
- St Anna Ziekenhuis
- Bergman Kliniek
- CosMed Kliniek
- Diakonessenhuis
- Faceland Kliniek
- Gelre Ziekenhuis
- Haaglanden Medisch Centrum
- Isala
- Maasstad Ziekenhuis
- MC Jan van Goyen
- Medisch Centrum Bloemendaal
- Onze Lieve Vrouwe Gasthuis
- Radboud Universitair Medisch C
- Rode Kruis Ziekenhuis
- Spaarne Gasthuis

- Academisch Centrum Amsterdam

- St Antonius Ziekenhuis

Berne Kliniek

- Canisius Wilhelmina Ziekenhuis

Erasmus Medisch Centrum

Flevoziekenhuis

- Groene Hart Ziekenhuis

- IJsselland Ziekenhuis

- Jeroen Bosch Ziekenhuis

- Martini Ziekenhuis

- MC Slotervaart

- Maastricht Universitair Medisch Centrum

Ommelander Ziekenhuis Groningen

Fig. 1 Number of respondents per participating center 
indicators are legally required for health care institutions and aim to monitor the quality of care), and 24 (23.5\%) to collect benchmark information (Fig. 2). Other motivations to register included increasing quality and safety $(2.0 \%)$, recall purposes $(5.9 \%)$, and scientific research $(2.0 \%)$.

Reasons for not registering included the following: (1) Registration was done by the supervising surgeon, (2) not being the main surgeon of the operation, or 3) not having performed breast implant surgery.

\section{Logistical challenges and user experiences}

To gain insight into the different logistical and administrative challenges of registration in the DBIR, a number of multiplechoice questions were asked.

Who registers Of all responding plastic surgeons, 79 (77.5\%) registered their cases personally. Five respondents $(4.9 \%)$ reported that the case was either registered by a plastic surgeon or by a resident (Fig. 3). For 23 respondents (22.5\%), the registration was performed by an administrative assistant, 12 respondents $(11.8 \%)$ reported that either an operating nurse or a physician assistant registered, and one respondent had a data manager who registered in the DBIR.

When do users register Forty-four plastic surgeons (44.4\%) registered immediately after the operation (i.e. while still in the operating room), 32 (32.3\%) registered somewhere else at a later moment (i.e. outside the operating room), and 23 $(23.2 \%)$ registered sometimes immediately in the operating room and sometimes somewhere else after the operation (Fig. 4).

How do users register Most respondents $(82,80.4 \%)$ registered directly via the online portal system, of whom $6(5.9 \%$ of total respondents) sometimes registered through batch uploads to DBIR via the electronic medical patient record (Fig. 5), 11 $(10.8 \%)$ used the paper surveys first, and $1(1.0 \%)$ used all the different registration methods. Just 6 respondents (5.9\%) solely filled out the paper surveys and 7 (6.9\%) solely used batch delivery to DBIR. Four respondents $(3.9 \%)$ indicated to register using either paper surveys or through batch delivery. Two respondents $(2.0 \%)$ did not answer this question.
The survey also quantified the awareness and use of the GS1 barcode scanning technology. The GS1 is a technique to provide a unique device identifier (UDI) to medical implants that can be printed as a barcode. This way, breast implants can be registered by scanning the functional Global Standards 1 (GS1) barcode field. This serves the purpose to (1) reduce registration burden, (2) increase data quality by reducing typing errors, and (3) use this for automation of data points in the future (Appendix 1). Only one plastic surgeon used the GS1 barcode scanner. Most of the respondents did not have a scanner available, or it was not linked to the electronic medical patient record.

\section{Areas of improvement}

Feedback for areas of improvement was asked in an openended question. Ninety-one respondents (89.2\%) suggested improvements for the DBIR. In summary, the following suggestions could be distinguished: (1) improve and simplify the method of data import (e.g., by decreasing the amount of questions or pre-loading data automatically through the electronic medical record system for example), (2) obligate the use of the GS1 barcode scanner, e.g., in order to decrease the chance of typing errors, (3) automate monitoring of incomplete data, (4) make a clearer lay-out of the registration file, (5) change the language of the registration to Dutch instead of English, (6) provide reports and feedback, and (7) show automatically generated national and local data for comparison after login.

\section{Discussion}

Previous literature underscores the importance of national breast implant registries in monitoring breast implant safety $[1,9,10]$. Recently, the results of public hearings run by the French ANSM, the Australian TGA, and the US FDA, in response to the issues on textured implants and BIA-ALCL, echo the advice to strictly register implant data. The present study sought to evaluate the perspective of the surgeons who are actually doing the registration and showed that surgeons believe that registration of breast implants is highly important ( 8.1 out of 10 points). This score can be translated as a 'green light' to continue the registration.

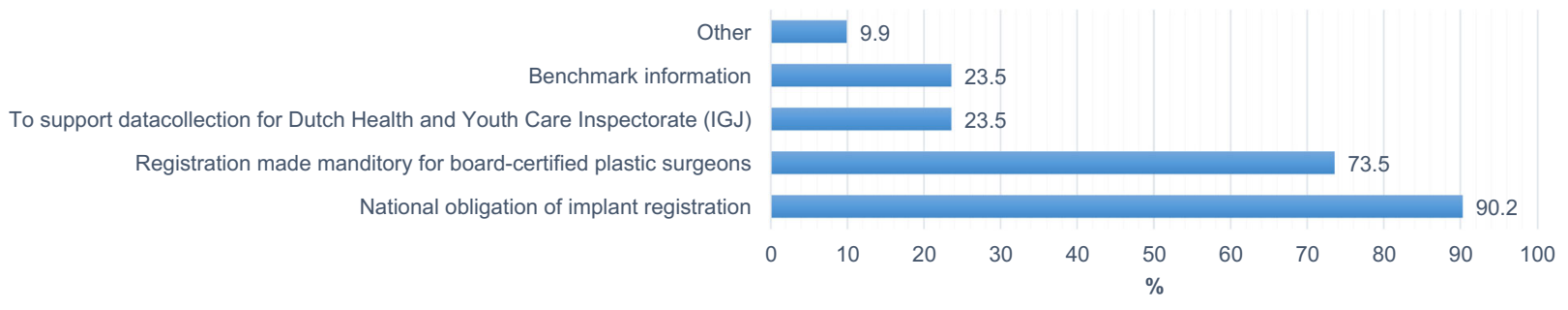

Fig. 2 Reasons for registration 
Fig. 3 Who registers

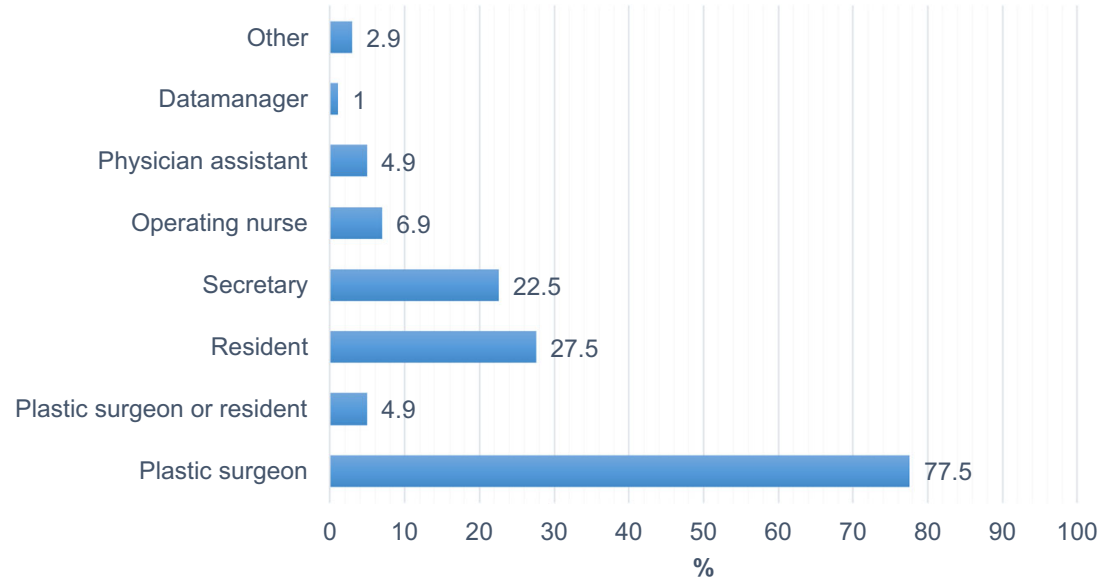

The results of this paper should be interpreted in light of its strengths and limitations. First, the survey was not a validated survey; however, the authors did run a pilot survey among fellow plastic surgeons from the DBIR committee. Second, the response rate of the questionnaire was $24.2 \%$. This may have introduced nonresponse bias. For example, it might be an overestimation that $97 \%$ percentage of the respondents register and that they rate the importance of registration 8.1 out of 10 points, as surgeons who are supportive of the registry might be more likely to complete the survey. The origin of the respondents did show an equal spread in terms of their geographical location across the country and their spreading across different hospitals (Fig. 1). Although this study is limited to its geographical (Dutch) scope, we believe the users' responses function as a new incentive and provide learning points that are easy to extrapolate to others who want to set up or improve breast implant registries.

Robust, (inter-)national breast implant registries are important [11]. However, there is also criticism towards the existence of national breast implant registries. To enable valid data comparisons not only nationally but also worldwide, DBIR questions are based on the international standard set as designed by the International Collaboration of Breast Registry
Activities (ICOBRA). Some believe registries could lead to invalid or 'bad' data, because the data is manually entered by the clinicians, and because the ICOBRA data set is not evidence based. Consequently, this could lead to loss of information about relevant characteristics [12]. In order to maintain and improve the quality of data, yearly improvements are made, quality control mechanisms are incorporated, and data points are updated. For example, immediate feedback is provided on missing and unlikely data, a signaling list on missing or erroneous data is added and since 2019, and a daily updated, interactive dashboard is available with information about patient characteristics and performances for participating institutions that show their outcomes compared to a Dutch benchmark (Codman Dashboard) [13]. Another important concern towards registration data is that it can be time consuming. By definition, a registry is dependent on physician participation. Therefore, a balance between registration burden, registration ease, and added value must always be deliberately considered when setting up a registry.

Also, when setting up a registry, individuals' privacy and national privacy laws should carefully be considered and respected, as legislation can make registration difficult. Differences in the interpretation of laws exist among health

Fig. 4 When do we register

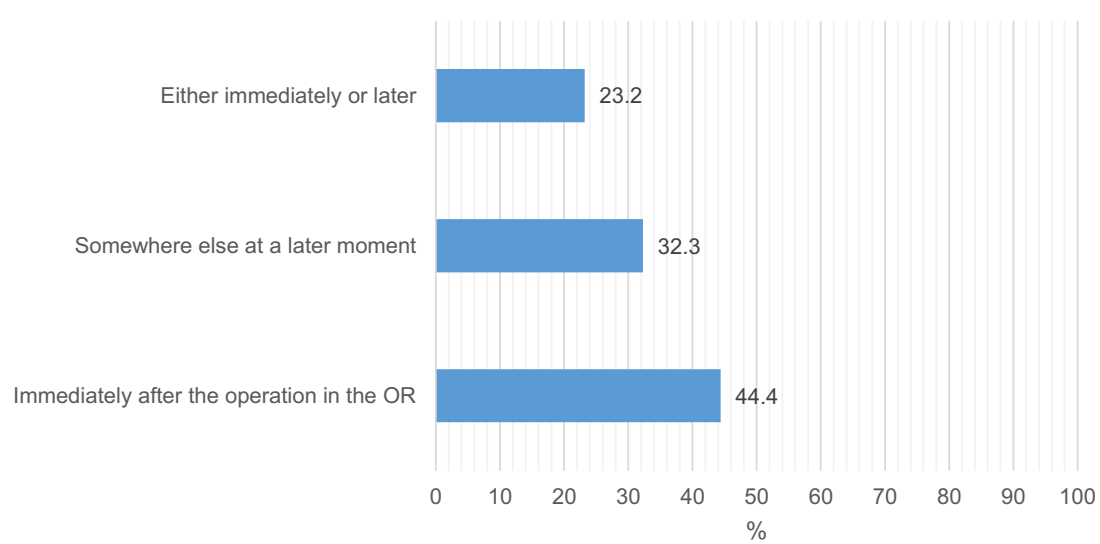


Fig. 5 How do we register

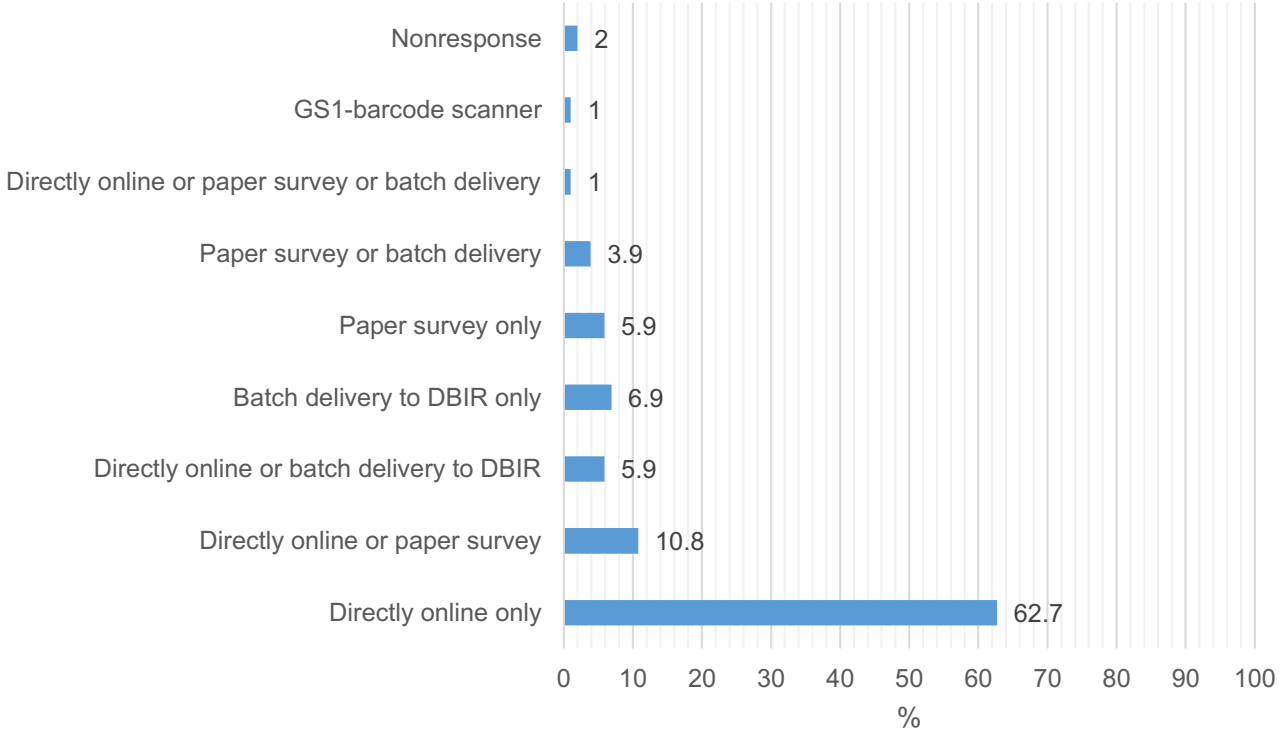

care institutions and countries. In the Netherlands, for example, the introduction of new privacy legislation puts clinical quality registries under pressure. The new law may complicate registration of citizen identification numbers, which makes it even harder to trace the implant back to individual patients. In order to comply with the General Data Protection Regulation (GDPR), the DBIR works with a certified Trusted Third Party (MRDM) to process the data [13]. The data which the DBIR receives from MRDM cannot be traced back to individuals.

Since users already consider registration of breast implants as highly important, the implant registration system should focus on optimization of the register. Addressing users' comments is pivotal to keep users actively engaged and motivated. Almost all surgeons, $89.1 \%$, suggested several improvements for the registry. This survey provides recommendations into which areas such improvements are required. All comments were related to registration convenience and provision of automatically generated (national and local) data. Considering the fact that the registration process relies on adherence of physicians' participation, improvement of the registry's user friendliness by improving its user interface is first priority. Automation of the registration process through the use of bar code scanners, intelligent and automated data uploading, and data point reduction are key to improve ease of use. Ideally, this process should be embedded in the operating room in order to support automated registration at the moment of implantation.

Improving registration convenience is especially important given the reasons why people register. As in any process, there are 'carrots', the reward for an action, and there are 'sticks', the punishment for not acting. In the case of the DBIR, the 'carrots' include having benchmarked data to measure an institutes' or departments' performance, generation of data that supports scientific research to confirm breast implant safety for patients, and a sense of 'professional pride'. The 'sticks' on the other hand, include measures such as making registration a requirement for board registration or a national quality indicator that is asked for by the Health Care Inspectorate, and shared with the general public. From this survey, it appears that 'sticks' are the most effective incentives that activate surgeons. Strikingly, the 'carrots', such as obtaining a bench mark and scientific research, are of less interest. However, we believe that better registration can also be reached by instating more efficient 'carrots'. Examples of this would include making the registry more functional, e.g. by automatically transferring data on adverse events, having reduced insurance fees when a surgeon shows compliance, or follow the Australian example by awarding physicians with professional development points for compliance to registration [10]. Moreover, increasing the awareness of the importance of adherence to the registration process by educating both colleagues and residents might further enhance physicians' participation.

The DBIR aims to work with automated data entry technologies in order to improve data entry comfort, and data quality in the future. For example, through registration with catalog numbers and unambiguous registration at the source, i.e., the electronic medical patient record ("Dutch: Registratie aan de bron"), all implant and relevant patient data will automatically be uploaded. Implementation of standard content, e.g., by implementing Systemized Nomenclature of Medicine-Clinical Terms (SNOMED CT), can support (inter-)national comparability of data.

The value of the GS1 barcode scanner is widely adopted; however, this survey showed that only one respondent used the GS1 barcode scanner and that the scanner was not available to most respondents. Therefore, the DBIR committee is working on making 
the GS1 barcode scanner available to everyone. As a result, more industrial suppliers are starting to include a GS1-compatible barcode on their implant boxes. Also, automatic content linking of the scanner to the electronic medical patient records should be provided for all. Modern ways of improving registries using artificial intelligence and machine learning, as incorporated in computer science decades ago should be the future. Multidisciplinary approaches with specialties outside the hospital, such as data science companies, may lead to useful new insights.

Today, the DBIR collects its data through either an online portal system (Appendix 3), or through batch delivery to DBIR via the electronic medical patient record. When registering through the online portal, surgeons are able to choose to register on a paper questionnaire first (Appendix 2). Eventually, the answers on the paper form have to be entered in the online portal. The paper version of the data points was designed to be used to fill out in a 'tick and stick' format in the operating room in order to subsequently hand it over to, for example, an administrative assistant to file the data points online. This was thought to be useful in reducing the administrative burden for the surgeon. However, this survey showed a clear preference for direct manual entry of data in the secure online portal $(80.4 \%)$, and that only $21.6 \%$ filled out the paper surveys. In support of data collection, various strategies are being developed:

1. Automatic uploads from hospital files. This survey showed that only a small portion of our data is now entered though this route; however, in the future, we aim to increase this use. In order to achieve this, leading hospital record software builders should be encouraged to agree on sharing templates between hospitals in a transparent way.

2. Development of a global breast implant catalogue. A high capture rate of reliable data at a national level that is internationally comparable through harmonized data sets is essential [11]. A global breast implant catalogue will enable the system to upload all the implant-specific data by entering the reference number of the implant. Moreover, it would uniform data entry, whereas now bias is caused, e.g., by users who are unaware of the texture gradient of the implants.

Our most used online registration method of data collection differs from the Australian Breast Device Registry (ABDR). The ABDR ensures data collection by collecting the paper forms filled out by the surgeons or the department staff, and subsequently double-checks and enters the paper data. Validation rules have been built into this database, but a paper-based system for data entry has several limitations: it may include incomplete fields and challenging handwriting, it is susceptible for transcription errors, and it is not environmentally friendly. Therefore, only using a smart web portal or mobile device system with adaptive pathways is considered priority in order to make registration easier, faster, and more complete. This example shows how different national registries can learn from each other by comparing experience and knowledge, in order to stimulate individual growth as well as international uniformity and comparability of data (quality).

Thus, in order to reach the best practice for our patients, we should collectively keep working on improvement of accuracy, usability, and sustainability of breast implant registries around the world. Mutual international collaborative initiatives and collaboration between different specialties will not only mitigate duplication of efforts of individuals but also amplify data sets and thus enable to detect implant-related problems at a much earlier stage [11]. One would hope that the excitement from the results of these DBIR user's experiences instigate further enthusiasm for the development of new national registries, and the expansion and improvement of the existing ones. In the context of this, discussion is of great importance within the world of plastic surgeons. Therefore, we would like to encourage those involved once more to publish about and to enter the debate around implant registers and how we can build further in a workable environment.

Code availability No custom computer code or algorithm was used to generate the results that are reported in this paper and central to its main claims.

Authors' contributions Each author has made substantial contributions to (1) the conception and design of the study, or acquisition of data, or analysis and interpretation of data, and (2) drafting the article or revising it critically for important intellectual content.

Data Availability The data that support the findings of this study are available on request from the corresponding author, HR. The data are not publicly available due to privacy restrictions of the respondents to this survey.

\section{Compliance with ethical standards}

Conflict of interest Claudia Antoinette Bargon, Babette E. Becherer, Danny Young-Afat, Annelotte C. M. van Bommel, Juliette Hommes, Marije J. Hoornweg, Ingrid Hopper, Marc A. M. Mureau, and Hinne A. Rakhorst declare that they have no conflict of interest.

Ethical approval The current study was centrally approved by the scientific board of the DBIR and the NVPC. This article does not contain any studies with human or animal subjects. The Medical Research Involving Human Subjects Act (WMO) does not apply to this study.

Informed consent Participating respondents consented to the use of this data for anonymized publication. 
Appendix 1. Example of functional GS1-field: in either a Matrix format or Barcode format.

Barcode field on implant box

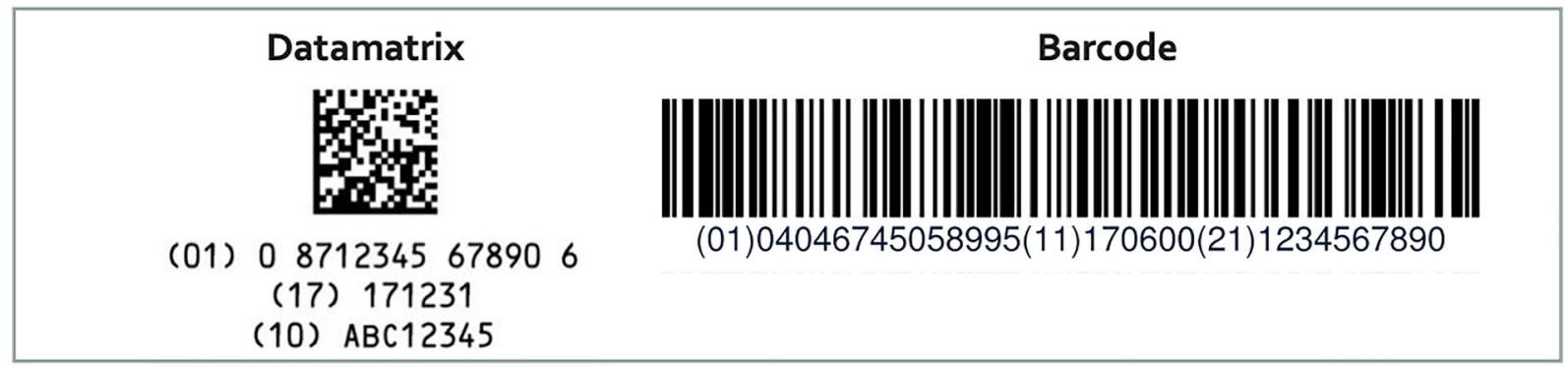




\section{Appendix 2. Example of paper version of regis- tration form (explantation only)}

\section{Dutch Breast Implant Registry}

DBIR-2019

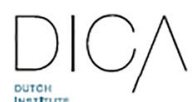

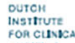

DBIR

DUTCH BREAST

IMPLANT REGISTRY

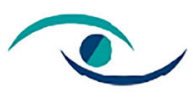

NVPC

versie: 2018-11-08 - 0.0.0 (interne code: dbir-2019) Online registratie:

\section{EXPLANTATION ONLY}

\section{PATIENT}

STICKER with

Country

Social security number

Local patient identification number

Initials

Prefix

Last name

Date of birth

HOSPITAL/PATIENT CHARACTERISTICS

HOSPITAL CHARACTERISTICS

Location

Operation date (dd/mm/yyyy)

Operating surgeon

PATIENT CHARACTERISTICS

ASA classification before operation

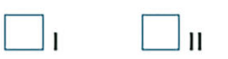

$\square$ III $\square$ IV $\square$ V

Unknown

\section{CASE-MIX VARIABLES}

Nicotine abuse

$\square_{\text {Yes }} \square_{\text {No }} \square$ Not known

Height in centimeters

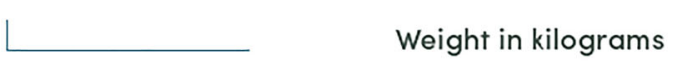

SYSTEMIC ANTIBIOTICS

Pre operative antibiotics

Post operative antibiotics

$\square$ Yes $\square$ No
$\square_{\text {Yes }} \square$ No




\section{SIDE}
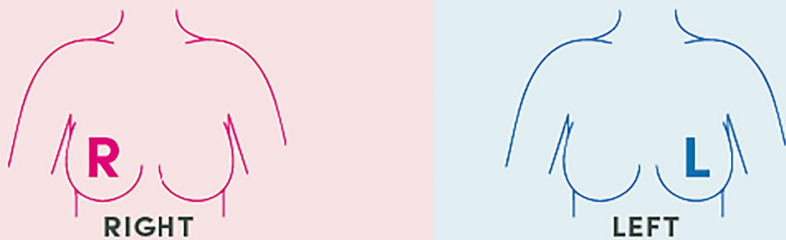

INTERVENTION

RIGHT LEFT

Indication of surgery

(cosmetic

RIGH

FT

LEFT

raction surgery

Timing reconstruction

Previous radiotherapy

Radiotherapy planned

Intervention

OPERATION TECHNIQUES

Incision site

Plane

\section{Capsulectomy}

Mastopexy

LD cover

Flapcover other than LD

Fat grafting

S

$\begin{aligned} & \begin{array}{l}\text { Cosmetic } \\ \text { augmentation }\end{array} \\ & \square \begin{array}{l}\text { Reconstruction } \\ \text { post mastectomy } \\ \text { for cancer }\end{array} \\ & \text { benign }\end{aligned}$
$\square \begin{aligned} & \text { Congenital } \\ & \text { deformity }\end{aligned}$
$\begin{aligned} & \text { Reconstruction post profylactic } \\ & \text { mastectomy }\end{aligned}$

$\square$ Immediate

$\square$ Delayed

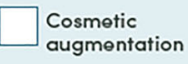

$\square$ Reconstructio post mastectomy

$\square$ Reconstruction

Congenital benign deformity

Reconstruction post profylactic mastectomy

$\square$ Immediate $\square$ Delayed

$\square$ Yes

$\square^{\text {No }}$

$\square$ Yes

No

Yes

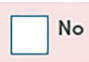

$\square$ Yes

\section{(n)}

No

\section{$\square$ Explantation only \\ $\square$ Explantation only}

RIGHT LEFT

$\square$ Inframammary $\square\left[\begin{array}{l}\text { Mastectomy scar } \\ \text { (general) }\end{array}\right.$ Inframammary $\quad \square\left[\begin{array}{l}\text { Mastectomy scar } \\ \text { (general) }\end{array}\right.$

$\square$ Axillary $\quad \square \begin{aligned} & \text { Mastectomy scar } \\ & \text { (nipple sparing) } \\ & \text { (nipple sparing) }\end{aligned} \quad \square$ Axillary

$\square^{\text {Areolar }} \quad \square \underset{\substack{\text { Lorsi) } \\ \text { Lotissimus }}}{\text { Areolar }} \quad \square$ LD (Latissimus

$\square$ Other $\square$ Other

\begin{tabular}{|c|c|c|c|}
\hline Subglandular & Sub fascial & Subglandular & Sub fascial \\
\hline Sub flap & Subcutaneous & Sub flap & Subcutaneous \\
\hline Sub pectoral & Dual plane & Sub pectoral & Dual plane \\
\hline
\end{tabular}

$\begin{array}{llll}\square^{\text {No }} & \square^{\text {Partial }} \square^{\text {Full }} & \square^{\text {No }} & \square^{\text {Partial }} \\ \square^{\text {Yes }} & \square^{\text {No }} & \square^{\text {Yes }} & \square^{\text {No }} \\ \square^{\text {Yes }} & \square^{\text {Yes }} & \square^{\text {No }} \\ \square^{\text {Yes }} & \square^{\text {Yes }} & \square^{\text {No }} \\ \square^{\text {Yes }} & \square^{\text {No }} & \square^{\text {Yes }} & \square^{\text {No }}\end{array}$


ANTISEPTIC PRECAUTIONS/DRAINS

Antiseptic rinse

Antiseptic rinse type

Sleeve/funnel

Nipple guards

Glove change for insertion

Drains

INDICATION FOR REVISION/EXPLANTATION SURGERY RELATED

\section{Replacement of TE with permanent implant}

Flap problem

Skin necrosis

Skin scarring problems

Deep wound infections

Seroma

Hematoma

\section{PATIENT}

Capsular contracture

Capsular contracture grade

\begin{tabular}{|c|c|c|c|}
\hline Yes & No & Yes & No \\
\hline $\begin{array}{l}\text { With betadine } \\
\text { solution }\end{array}$ & $\begin{array}{l}\text { With antibiotic } \\
\text { solution }\end{array}$ & $\begin{array}{l}\text { With betadine } \\
\text { solution }\end{array}$ & $\begin{array}{l}\text { With antibiotic } \\
\text { solution }\end{array}$ \\
\hline \multicolumn{2}{|c|}{$\begin{array}{l}\text { With combination of betadine and } \\
\text { antibiotic solution }\end{array}$} & \multicolumn{2}{|c|}{$\begin{array}{l}\text { With combination of betadine and } \\
\text { antibiotic solution }\end{array}$} \\
\hline
\end{tabular}

$\square$ Yos

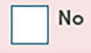

$\square$ Yes

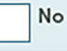

$\square$ Yos

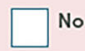

$\square$ Yos

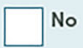

$\square$ Yos

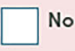

$\square$ Yes

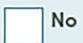

$\square$ Yos

$\square^{\text {No }}$

$\square$ Yos

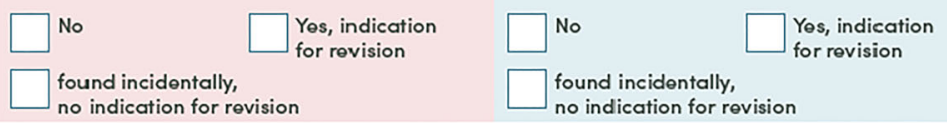

$\square_{\text {found incidentally, }}^{\text {No }} \quad \square$ for revision
no indication for revision $\square$ No
$\square$ found incidentally,
no indication for revision

$\square$ Yes, indication for revision

$\square$ No $\quad \square$ Yes, indication
for revision
$\square$ found incidentally,
no indication for revision
$\square$ No $\square$ Yos, indication
found incidentally, no indication for revision

$\square$ No
$\square$ for, indication
$\square$
found incidentalion
no indication for revision
No $\square$ Yes, indication
$\square$ found incidentally, no indication for revision

$\square$ No $\quad \square$ Yos, indication
$\square_{\text {for revision }}^{\text {found incidentally, }}$ no indication for revision
$\square$ No $\quad \square$ Yes, indication
found incidentally, no indication for revision

$\square$ No
$\square$ fos, indication
$\square$
found incidentalion
no indication for revision
$\square$ No $\quad \square \begin{aligned} & \text { Yes, indication } \\ & \text { for revision }\end{aligned}$
found incidentally,

no indication for revision

\begin{tabular}{|c|c|c|c|}
\hline No & $\begin{array}{l}\text { Yes, indication } \\
\text { for revision }\end{array}$ & No & $\begin{array}{l}\text { Yes, indication } \\
\text { for revision }\end{array}$ \\
\hline & & & \\
\hline
\end{tabular}


INDICATION FOR REVISION/EXPLANTATION

Newly diagnosed breast cancer

Suspicion of BIA-ALCL

PA confirmed BIA-ALCL

ASIA syndrome

Breast pain

Asymmetry

Patient dissatisfied with volume

\section{DEVICE}

Device rupture or Device deflation

$\square$ No $\quad \square$ Yos, indication
for revision
$\square$
$\begin{aligned} & \text { found incidentally, } \\ & \text { no indication for revision }\end{aligned}$

Silicone extravasation

Silicone extravasation type

Device malposition

Recall

Other (describe)

\section{No \\ found incidentally, \\ no indication for revision}

$\square$ No $\square$ Yes, indication
for revision

$\square^{\text {No }} \quad \square_{\text {for revision }}^{\text {Yes incation }}$ for

found incidentally,

no indication for revision

$\square$ No $\square$ Yes, indication
for revision

$\square$ No $\square$ Yos, indication
for revision
$\square$ found incidentally,
no indication for revision
$\square$ No $\quad$ Yes, indication
found incidentally,
no indication for revision

$\square$ No $\square$ Yos, indication
for revision

\section{RIGHT LEFT}

No

$\square$ Yes, indication

found incidentally,

no indication for revision
Intra capsular
$\square$ No $\quad \square$ Yes, indication
found incidentally,
no indication for revision

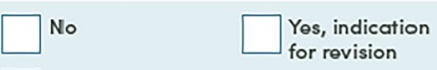

found incidentally,

no indication for revision
$\square$ No $\quad \square$ Yos, indication
$\square$ found incidentally,
no indication for revision
$\square$ No $\square$ Yes, indication
found incidentally, no indication for revision
$\square$ No $\quad \square \begin{aligned} & \text { Yes, indication } \\ & \text { for revision }\end{aligned}$
found incidentally, no indication for revision

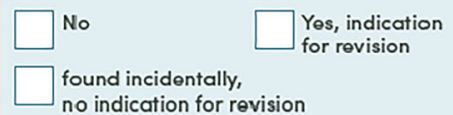

no indication for revision 


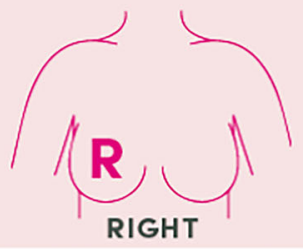

RIGHT

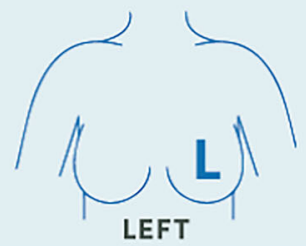

LEFT

Is the device inserted or removed?

$\square$ Removed

Removed

Device type

$\square_{\text {device }}^{\text {Permanent }} \quad \square=0$ expander

Are you removing a device

inserted at another clinic?

$\square$ Yos
$\square$ Not known

Are you removing a device inserted abroad?

Is the name of the other clinic known?

Name other clinic

Country

DEVICE SPECIFIC INFORMATION

Medical records or device passport

Identifyable markers on implant

Texture

Coating

$\begin{array}{ll}\square \text { Germany } & \square \text { Bolgium } \\ \square \text { France } & \square \text { UK } \\ \square \text { Turkey } & \square \text { Thailand } \\ \square \text { Elsewhere } & \end{array}$

$\square$ Yos

$\square$ No

Not known

Other country

Year of implantation (yyyy)
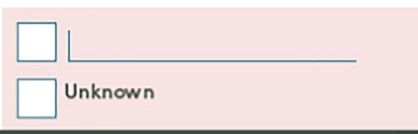

$\square$ Yes $\quad \square \begin{aligned} & \text { No previous infor- } \\ & \text { mation available }\end{aligned}$

Yos

$\square$ Micro textured $\square$ Macro textured
$\square$ Nano textured $\square$ Smooth

$\square$ No

$\square$ Yos $\square$ Not known

$\square \begin{aligned} & \text { Permanent } \\ & \text { device }\end{aligned} \quad \square$ expander

$\square$ Yos

$\square$ No

Not known

(a)

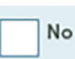

No

No

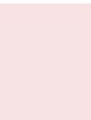

$\square$

$\square$ Unknown

RIGHT LEFT

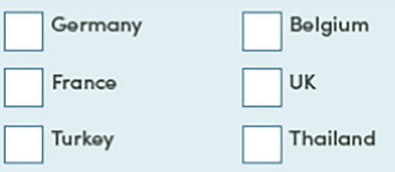

$\square$ Elsewhere

No identifyable

$\square$ Yos mation mation crailable

\section{$\square$ Micro textured \\ $\square$ Nano textured} markers

$\square$ Silicone $\square$ Polyurethane

$\square$ Other

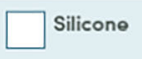

$\square$ Other

\section{$\square$ Macro textured}

$\square$ Smooth

Coating other (describe) 
DEVICE SPECIFIC INFORMATION

RIGHT LEFT

Fill

\begin{tabular}{|c|c|c|c|}
\hline Silicone & Saline & Silicone & Saline \\
\hline Hydrogel & Air & Hydrogel & Air \\
\hline Other & & Other & \\
\hline
\end{tabular}

Fill other (describe)

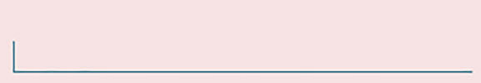

Shape

$\square$ Round $\quad \square$ Shaped/ anatomical

$\square$ Round

Shaped/

DEVICE MANUFACTURER

RIGHT

Manufacturer

\begin{tabular}{|c|c|}
\hline Other & $\begin{array}{l}\text { Allergan } \\
\text { (Natrella) }\end{array}$ \\
\hline B-Lite & $\begin{array}{l}\text { Cereplas } \\
\text { (Cereform) }\end{array}$ \\
\hline $\begin{array}{l}\text { CUI/Cox Uphoff } \\
\text { Implants }\end{array}$ & $\begin{array}{l}\text { EMSI } \\
\text { Biomedical }\end{array}$ \\
\hline $\begin{array}{l}\text { Establishment } \\
\text { Labs (Motiva) }\end{array}$ & $\begin{array}{l}\text { GC Aesthetics } \\
\text { (Eurosilicone) }\end{array}$ \\
\hline $\begin{array}{l}\text { GC Aesthetics } \\
\text { (Nagor) }\end{array}$ & Groupe Sebbin \\
\hline $\begin{array}{l}\text { Laboratoires } \\
\text { Arion (Monobloc) }\end{array}$ & Mentor \\
\hline $\begin{array}{l}\text { Pérouse Plastio } \\
\text { SAS }\end{array}$ & $\begin{array}{l}\text { PIP / } \\
\text { M-implants }\end{array}$ \\
\hline $\begin{array}{l}\text { Polytech Health Q } \\
\text { Aesthetics }\end{array}$ & Silimed \\
\hline Surgitek & \\
\hline
\end{tabular}

$\square$ Other

Manufacturer

L

Other

Reference No.

Lot number

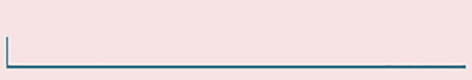

$\square$ B-Lite

$\square$ CUI/Cox Uphoff

$\square$ Establishment

Labs (Motiva)

$\square$ GCAesthetics

$\square$ Laboratoires Arion (Monobloc) $\square$ Pérouse Plastie

$\square$ Polytech Health Q Aesthetics

$\square$ Surgitek

$(2$ 


\section{Appendix 3. Example of first two pages of on- \\ line registration form (anonymized)}

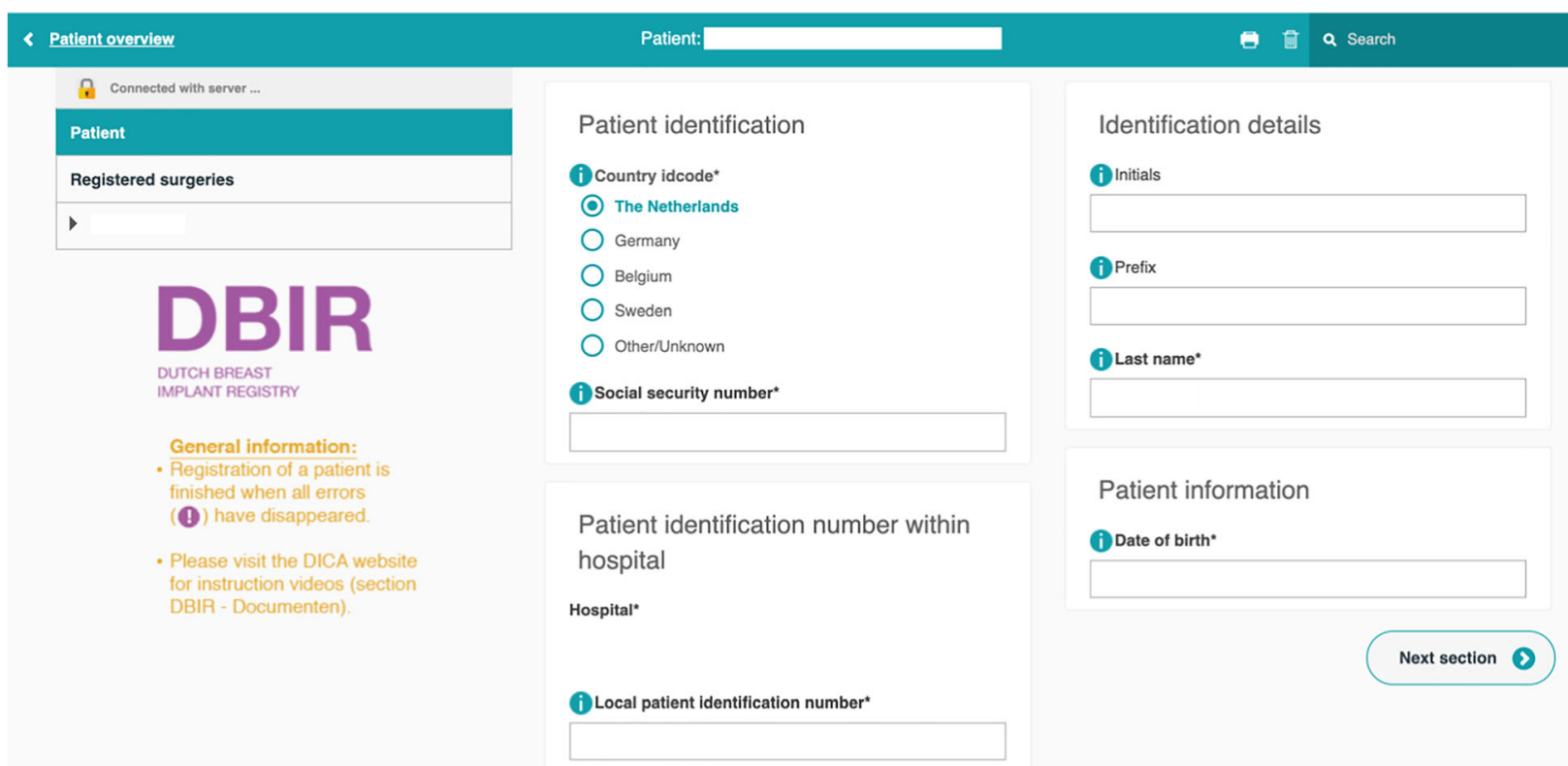

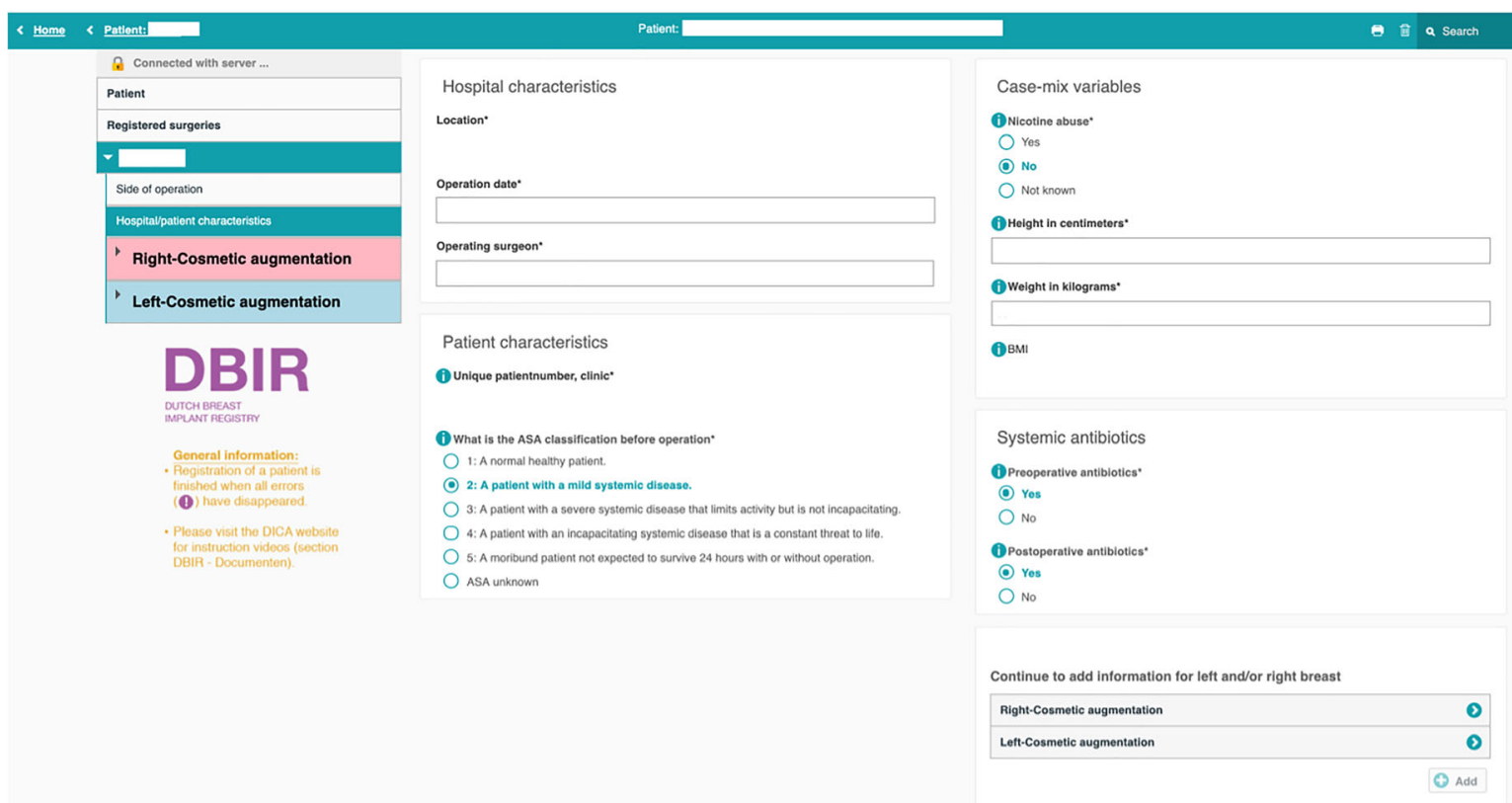




\section{References}

1. de Boer M, van Leeuwen FE, Hauptmann M, Overbeek LIH, de Boer JP, Hijmering NJ et al (2018) Breast implants and the risk of anaplastic large-cell lymphoma in the breast. JAMA Oncol. 4(3): 335-341

2. Becherer BE, de Boer M, Spronk PER, Bruggink AH, de Boer JP, van Leeuwen FE et al (2019) The Dutch Breast Implant Registry: registration of breast implant-associated anaplastic large cell lymphoma-a proof of concept. Plast Reconstr Surg. 143(5):12981306

3. U.S. Food and Drug Administration. FDA update on the safety of silicone gel-filled breast implants - executive summary. https:// www.fda.gov/media/80707/download. Last updated: July 16, 2018. [Accessability verified November 22, 2019].

4. de Boer M, van Middelkoop M, Hauptmann M, van der Bijl N, Bosmans JAW, Hendriks-Brouwer N, Schop et al (2019) Breast implant prevalence in the Dutch female population assessed by chest radiographs. Aesthet Surg J sjz136

5. Leberfinger AN, Behar BJ, Williams NC, Rakszawski KL, Potochny JD, Mackay DR et al (2017) Breast implant-associated anaplastic large cell lymphoma: a systematic review. JAMA Surg. 152(12):1161-1168

6. U.S. Food and Drug Administration. Breast implant-associated anaplastic large cell lymphoma (bia-alcl). https://www.fda.gov/ medical-devices/breast-implants/breast-implant-associatedanaplastic-large-cell-lymphoma-bia-alcl. Last updated: October 23, 2019. [Accessability verified November 22, 2019].
7. Rakhorst HA, Mureau MAM, Cooter RD, McNeil J, van Hooff M, van der Hulst R et al (2017) The new opt-out Dutch National Breast Implant Registry - lessons learnt from the road to implementation. J Plast Reconstr Aesthet Surg. 70(10):1354-1360

8. Becherer, B.E., under the supervision of the DBIR committee. Annual Report DBIR 2017. http://dica.nl/media/2165/DBIR\% 20Annual\%20report\%20(2015-2017).pdf. Last updated: November, 2018. [Accessability verified November 22, 2019].

9. Becherer BE, Spronk PER, Mureau MAM, Mulgrew S, Perks AGB, Stark B et al (2018) High risk device registries: global value, costs, and sustainable funding. J Plast Reconstr Aesthet Surg. 71(9): $1362-1380$

10. Clemens MW (2019) Discussion: The Dutch Breast Implant Registry: registration of breast implant-associated anaplastic large cell lymphoma-a proof of concept. Plast Reconstr Surg. 143(5): 1307-1309

11. Cooter RD, Barker S, Carroll SM, Evans GR, von Fritschen U, Hoflehner $\mathrm{H}$ et al (2015) International importance of robust breast device registries. Plast Reconstr Surg. 135(2):330-336

12. Brown T (2017) Commentary on "The new opt-out Dutch National Breast Implant Registry - lessons learnt from the road to implementation". J Plast Reconstr Aesthet Surg. 70(10):1361-1362

13. Becherer BE, under the supervision of the DBIR, committee. Annual Report DBIR 2018. https://dica.nl/media/2182/DBIR\% 20Annual\%20report\%20(2018).pdf. Last updated: November, 2019. [Accessability verified November 22, 2019].

Publisher's note Springer Nature remains neutral with regard to jurisdictional claims in published maps and institutional affiliations. 